(Q)
SPEDM

Caso Clínico

\title{
Diabetic Ketoacidosis after Bariatric Surgery: A Case Report
}

\author{
Fernando Miguel Mendonça a,*, Maria Manuel Silva ${ }^{a}$, Vanessa Chaves ${ }^{\text {b }}$, Selma Souto a, \\ Paula Freitas ${ }^{\text {a }}$, Davide Carvalho ${ }^{\text {a }}$
}

a Department of Endocrinology, Diabetes and Metabolism / Centro Hospitalar e Universitário de S. João, Porto, Portugal

${ }^{b}$ Department of Internal Medicine / Centro Hospitalar e Universitário de S. João, Porto, Portugal

\begin{abstract}
INFORMAÇÃO SOBRE O ARTIGO
Historial do artigo:

Received/ Recebido: 2020-07-11

Accepted/Aceite: 2020-11-09

Final: 2021-01-19

(C) Autor (es) (ou seu (s) empregador (es)) e Revista SPEDM 2020. Reutilização permitida de acordo com CC BY-NC. Nenhuma reutilização comercial.

(C) Author(s) (or their employer(s)) and SPEDM Journal 2020. Re-use permitted under CC BY-NC.

No commercial re-use.

A B S T R A C T

A 60-year-old woman with diabetes mellitus was followed in endocrinology consultations since 2018 , due to uncontrolled diabetes (HbA1c on 09/2018 - 9.3\%). She was medicated with metformin/ dapagliflozin 1000/5 mg bid and with a pre-mixed suspension (30\% aspart insulin/70\% NPH insulin, 16 IU before breakfast, 24 IU before lunch, and 24 IU before dinner. Her past medical history comprises hypertension, dyslipidemia, and morbid obesity (BMI $40.6 \mathrm{~kg} / \mathrm{m}^{2}$ ), as well as a proliferative diabetic retinopathy. She was submitted for bariatric surgery and was discharged with metformin/ dapagliflozin $1000 / 5 \mathrm{mg}$ bid, the insulin being abruptly stopped. She was later admitted to the emergency department due to a diabetic ketoacidosis. After aggressive fluid therapy with insulin and the correction of electrolytic disturbances, there was a regression of this pathological presentation. This clinical case stresses the importance of a correct and multidisciplinary approach for antidiabetic therapy during the pre, peri, and post-surgical period among bariatric patients.
\end{abstract}

\section{Keywords:}

Bariatric Surgery;

Diabetic Ketoacidosis;

Obesity, Morbid/surgery.

Palavras-chave:

Cetoacidose Diabética;

Cirurgia Bariátrica;

Obesidade Mórbida/cirurgia.

\section{Cetoacidose Diabética Após Cirurgia Bariátrica: A Propósito de um Caso Clínico}

\section{R E S U M O}

Doente do sexo feminino, 60 anos, diabetes mellitus diagnosticada há 20 anos em análises de rotina. Seguida em consulta de endocrinologia desde 2018 por diabetes descompensada (HbA1c em 09/2018 - 9,3\%). Encontrava-se medicada com metformina/dapagliflozina 1000/5 mg bid e com uma pré-mistura (30\% insulina aspart e 70\% insulina isofânica) com 16UI antes do pequenoalmoço, 24UI antes do almoço e 24UI antes do jantar. Apresentava antecedentes de hipertensão, dislipidemia, obesidade mórbida (BMI $40,6 \mathrm{~kg} / \mathrm{m}^{2}$ ) e retinopatia diabética proliferativa. A doente foi submetida a cirurgia bariátrica e teve alta com metformina/dapagliflozina 1000/5 mg bid, tendo a insulinoterapia sido suspensa abruptamente. Posteriomente, foi admitida no serviço de urgência por cetoacidose diabética. Após fluidoterapia agressiva e correção dos distúrbios hidroelectrolíticos, verificou-se uma regressão do quadro patológico. Este caso reforça a importância de uma abordagem correta e multidisciplinar para a terapêutica antidiabética nestes doentes durante o período pré, peri e pós-operatório de doentes submetidos a cirurgia.

\footnotetext{
* Autor Correspondente / Corresponding Author.

E-Mail: fernandomiguel_92@hotmail.com (Fernando Mendonça)

Alameda Prof. Hernâni Monteiro, 4200-319 Porto, Portugal
} 


\section{Introduction}

Obesity, which is defined as a body mass index (BMI) $\geq 30 \mathrm{~kg} /$ $\mathrm{m}^{2}$, constitutes a severe and complex public health problem which results from an imbalance between food ingestion and energy expenditure. According to the World Health Organization, in 2016, $39 \%$ of the adults in the world were overweight, and $13 \%$ had obesity. ${ }^{1-3}$ In Portugal, this scenario is even worse among adult people, with approximately $50 \%$ of adults being overweight, and $20 \%$ having obesity. ${ }^{4}$ One of the most frequently related pathologies with obesity is type 2 diabetes (T2D). A modest weight loss (of about $5 \%$ of body weight) can be enough to lessen the impact of T2D among these patients, which is a fact that gains even more importance when we consider that more than $90 \%$ of patients with T2D are overweight or obese. ${ }^{5}$

Obesity therapeutic options which promote sustained weight loss (such as bariatric surgery) are becoming increasingly popular, as they reduce comorbidity whilst increasing the quality of life of patients. ${ }^{6}$ The American Diabetes Association (ADA) acknowledges that, although bariatric surgery is recommended as an option for adults with BMI $\geq 40 \mathrm{~kg} / \mathrm{m}^{2}$ or with BMI $\geq 35 \mathrm{~kg} / \mathrm{m}^{2}$ and associated comorbidities, it may also be considered for those with BMI $\geq 30 \mathrm{~kg} / \mathrm{m}^{2}$ and type 2 diabetes who do not achieve sustained weight loss and improvement in comorbidities (including hyperglycemia).

Although most patients with obesity submitted for bariatric surgery have T2D, the differential diagnosis of this type of diabetes is difficult in certain particular cases. This occurs because the clinical frontier between latent autoimmune diabetes in adults (LADA) and T2D is sometimes very thin, given the long duration of marginal insulin secretory capacity in both types of diabetes. The distinction between these two entities can be made in some cases through the evaluation of autoimmune markers, such as islet cell autoantibodies, autoantibodies to glutamic acid decarboxylase (anti-GAD), insulin, tyrosine phosphatases IA-2 and IA-2b, and zinc transporter 8 (ZnT8). ${ }^{8}$

During the post-operatory period of bariatric surgery, managing antidiabetic medication poses a major challenge for those health professionals who follow these patients, ${ }^{9}$ even more so when the type of diabetes is uncertain. An incorrect management of the antidiabetic therapy can result in severe consequences which can be fatal if a timely diagnosis is not made. We report a case of a patient treated with SGLT2 inhibitor (SGLT2i) who developed ketoacidosis after insulin withdrawal on discharge from bariatric surgery.

\section{Case Report}

A 60-year-old woman, with diabetes mellitus which had been diagnosed at the age of 40 during a routine biochemistry evaluation, presented obesity with no catabolic symptoms at the time of diagnosis. She had been under insulin therapy since the age of 42, having initially been followed by her family doctor. Her diabetes became decompensated over time, which was a reason which motivated the reference of this patient for an endocrinology consultation at the Pedro Hispano Hospital, in 2018 (with levels of HbA1c of $9.3 \%$ in September 2018, and 8.5\% in March 2019). She had been recently medicated with metformin/dapagliflozin 1000/5 mg twice daily and with a pre-mixed neutral suspension comprised of rapid-acting insulin aspart (30\%) and longer-acting protamine insulin aspart (70\%), with $16 \mathrm{IU}$ before breakfast, 24 IU before lunch, and 24 IU before dinner.

The patient presented a blood analysis of March 2019 with a C peptide of $1.02 \mathrm{ng} / \mathrm{mL}(1.1-4.4)$ and negative anti-GAD antibodies. No previous $\mathrm{C}$ peptide or autoimmunity markers were documented. Her parents had T2D, with no other relevant pathologies in her family (including autoimmune diseases). Regarding target organ damage, she presented proliferative diabetic retinopathy submitted to photocoagulation, followed by a consultation with an Ophthalmology outpatient clinic. The patient presented no other diabetic micro or macrovascular complications. She had other comorbidities, such as hypertension, obstructive sleep apnea syndrome, dyslipidemia, and morbid obesity (BMI $40.6 \mathrm{~kg} / \mathrm{m} 2$ ). She was submitted to bariatric surgery - Roux-en-Y gastric bypass - on 09/09/2019, at another hospital. When asked about glycemic control after surgery during this hospitalization, the patient mentioned that she was under insulin therapy, although she did not remember the glycemic values. The patient was discharged on the third postoperative day with metformin/dapagliflozin 1000/5 mg twice daily and a liquid diet, without any insulin. The day after being discharged from hospital, she started to present symptoms of severe asthenia, nausea, polydipsia, and dizziness, which worsened over time. The patient added that her glycemic profile at home ranged between 200 and $300 \mathrm{mg} /$ $\mathrm{dL}$, despite not being eating properly. Thirteen days after surgery, she was sent to the emergency department due to an altered state of consciousness (psychomotor retardation) and the maintenance of the other symptomatology. The patient said that she did not have a fever, neither abdominal pain, nor cardiorespiratory, genitourinary, or any other complaints.

On physical examination at admission, the patient presented drowsiness (was easily awakened), however she was well-oriented in terms of space and time, with no focal neurological deficits. Mucosae and skin were flushed and dehydrated, with no signs of poor peripheral perfusion. She had an auricular temperature of $36.2^{\circ} \mathrm{C}$, with polypnea and a blood pressure of $137 / 59 \mathrm{mmHg}$, a heart rate of 88 beats per minute, and oxygen saturation of $100 \%$ (room air). Cardiac auscultation revealed rhythmic S1 and S2, without murmurs. Auscultation of the lungs exhibited no abnormalities, as did an abdominal examination. She had abdominal bandages (which were related with the prior bariatric surgery) which were dry and clean. No peripheral edema was detected. The patient presented no other relevant findings during a physical exam.

The results of the gasometrical and analytical study (Table 1) revealed hyperglycemia associated with metabolic acidosis, an in-

Table 1. Results at admission to the Emergency department.

\begin{tabular}{lcc}
\hline Parameter & Result & $\begin{array}{c}\text { Reference } \\
\text { values }\end{array}$ \\
\hline pH & 7.0 & $7.35-7.45$ \\
\hline pCO2 (mmHg) & 7.5 & $35-45$ \\
\hline HCO3- (mmol/L) & 2.0 & $22-29$ \\
\hline Anion gap (mmol/L) & 31 & $8-12$ \\
\hline K+ (mEq/L) & 6.0 & $3.5-5.0$ \\
\hline Glucose (mg/dL) & 498 & $75-110$ \\
\hline Leucocyte count (x10^9/L) & 7.39 & $4.0-11.0$ \\
\hline PCR (mg/L) & 9.5 & $<3$ \\
\hline Lipase (U/L) & 74 & $<-60$ \\
\hline Glucose - urine (mg/dL) & $>1000$ & $<10$ \\
\hline Ketone bodies - urine (mg/dL) & $>80$ & 100 \\
\hline
\end{tabular}


creased anion gap, ketonuria, and glycosuria, with no relevant increase in C-reactive protein, leukocyte count, or lipase. No value of ketonemia at admission was documented in the clinical records. Thoracic and abdominal radiographic studies presented no alterations. The patient was diagnosed with diabetic ketoacidosis due to insulin therapy omission and SGLT2 inhibitor maintenance during the post-operatory period of bariatric surgery.

The patient was admitted to the intermediate care unit, where she proceeded to undergo treatment for diabetic ketoacidosis. Next, she was transferred to our Endocrinology department to optimize the insulin therapy, and demonstrated a progressive improvement of glycemic control. Five days later, the patient was discharged with a basal/bolus insulin regimen - degludec 26 IU at night and a sliding scale of insulin lispro 2 IU three times a day before the main meals, attaining a target of $90-140 \mathrm{mg} / \mathrm{dL}$, and an insulin sensitivity factor (ISF) of 50. The blood work-up during her hospitalisation revealed a $\mathrm{HbA} 1 \mathrm{c}$ of $8.6 \%$, C peptide of $0.61 \mathrm{ng} / \mathrm{mL}$ (1.1-1.4), fasting glucose of $158 \mathrm{mg} / \mathrm{dL}$ and negative anti-insulin antibodies (the anti-GAD antibodies were negative, as previously mentioned).

Five weeks after the ketoacidosis episode ( 7 weeks after surgery), she attended an endocrinology consultation, where she presented a HbA1c of 7.6\% under insulin therapy - 20 IU of insulin degludec at night, and a sliding scale of insulin lispro before the main meals (4 IU to attain a target of $90-140 \mathrm{mg} / \mathrm{dL}$, with ISF of 50). She was then referred to the Endocrinology department for follow-up and further adjustments of the insulin therapy.

\section{Discussion}

This clinical report shows the development of diabetic ketoacidosis (DK) in a patient with morbid obesity who had been submitted to bariatric surgery. DK is one of the most severe acute complications of diabetes, and is considered to be a medical emergency. This clinical entity is defined by a triad of hyperglycemia (glucose $\geq 250 \mathrm{mg} / \mathrm{dL}$ ), metabolic acidosis, and ketonemia. ${ }^{10,11}$ It is of primordial importance the identification of precipitant factors for DK. The main ones are therapeutic non-compliance (mainly insulin therapy), infections, trauma/surgery, iatrogeny, and various medications such as SGLT2i. ${ }^{10}$ The growing use of these medications in the clinical practice has led to an increase of the number of DK cases. Albeit the majority of them are of euglycemic DK, ${ }^{12}$ few hyperglycemic DK have been reported in the literature. ${ }^{13}$

There are several case reports of DK after bariatric surgery, ${ }^{14,15}$ but what makes this case unique is the aggregation of multiple DK triggers in the same patient. The main causative factor seems to be the abrupt suspension of insulin therapy in a patient who was medicated with more than $60 \mathrm{IU}$ per day (and who presented poor glycemic control, despite this dose of insulin). In addition, bariatric surgery by itself is a stressor factor, which is followed by a period of a very restrictive liquid diet, predisposing an increase in lipolysis, which leads to the production of ketone bodies. This fact can, during extreme circumstances, lead to clinical ketoacidosis even in individuals without diabetes. ${ }^{16,17}$ Finally, the maintenance of SGLT2i (dapagliflozin) treatment in a patient with endogenous insulin deficit and the abrupt insulin suspension, must also have contributed to this adverse outcome.

The type of diabetes mellitus in this patient is also an important issue. A 60-year-old woman, with obesity and with at least 20 years of diabetes duration was diagnosed during a routine biochemical blood test without symptoms and with family history of T2D. In addition, no positive autoimmune markers were detected in the blood analysis (namely, anti-insulin or anti-GAD antibodies). These are important arguments to consider for the diagnosis of T2D. The diminished C peptide $(0.61 \mathrm{ng} / \mathrm{mL})$ observed during DK hospitalisation, can be explained by the verification of an advanced stage of T2D. T2D is a progressive disease which is characterised by insulin resistance, with relative insulin deficiency, which causes a gradual decline in beta cell-function as the disease evolves. This fact ultimately leads to absolute insulin deficiency (which is mirrored by low $\mathrm{C}$ peptide levels) and the need for exogenous insulin during the late stages of the disease. ${ }^{8,18}$ For this reason, albeit less common, it is also possible to develop DK among T2D patients who have a history of a long duration of disease. ${ }^{9}$

It is relevant to point out that anti-GAD antibodies tend to become negative as the diabetes mellitus evolves, ${ }^{19}$ and that, in this particular case, antibodies were sought only 20 years after diagnosis. The negativity of anti-GAD and anti-insulin antibodies do not invalidate the hypothesis that other autoimmune markers could be positive (such as islet cell antibodies and autoantibodies to IA-2 and IA-2ßtyrosine phosphatases and the zinc transporter 8). Among the cases of autoimmune diabetes, the rate of pancreatic $\beta$-cell destruction varies considerably, being fast in some patients, and slow in others (mainly adults). Adult patients can have diminished $ß$-cell function and a low insulin level, which is sufficient to prevent ketoacidosis occurrence for many years. With the continuous autoimmune islet cell destruction, the patient becomes progressively more dependent on insulin to survive and is at risk of ketoacidosis. At this latter stage, little or no insulin is produced, as indicated by low or undetectable levels of plasmatic C-peptide. ${ }^{8}$

The fact that our patient required an average of 30 IU of insulin daily (basal-bolus routine) to be able to achieve metabolic control seven weeks after bariatric surgery, only strengthens the idea that patients who are "cured", or who demonstrate diabetes remission are those with $\mathrm{T} 2 \mathrm{D}$, who are young, with less disease duration, and who need lower insulin doses (with a better pancreatic reserve). ${ }^{20}$ Consequently, after weighing the presented pros and cons, it seems that this patient probably has an advanced stage T2D, with absolute insulin deficiency, which has become decompensated with DK after abrupt insulin suspension and concomitant SLT2 $i$ therapy during the postoperative period of bariatric surgery.

This case report shows the importance of the existence of a multidisciplinary team including an endocrinologist for diabetes treatment during the pre, peri, and post-surgical period of bariatric surgery. The management of diabetes in these patients can be complex, and the main guidelines of bariatric surgery do not always represent the best approach for long term antidiabetic therapy after surgery. ${ }^{21,22}$ To fill this gap, the Portuguese Society for the Study of Obesity (SPEO) recently published a nutritional and pharmacological guideline for diabetic patients after bariatric surgery. This paper states that, although there is no consensus, some authors defend a $50 \%$ reduction in the basal insulin associated with a sliding scale of a fast-acting insulin before main meals, with adjustment of doses according to patients needs. Those with T2D who still require insulin on discharge should carry on insulin therapy at home, with monitoring of blood glucose, with progressive insulin dose reductions (if needed) in order to avoid hypoglycemia. Regarding SGLT2i therapy in bariatric patients, this guideline recommends the suspension of this pharmaceutical class at least 24 hours before surgery. It also stresses the idea that SGLT2i should not be initiated in the immediate postoperative period to avoid postoperative diabetic ketoacidosis. ${ }^{23}$ 


\section{Responsabilidades Éticas}

Conflitos de Interesse: Os autores declaram a inexistência de conflitos de interesse na realização do presente trabalho.

Fontes de Financiamento: Não existiram fontes externas de financiamento para a realização deste artigo.

Confidencialidade dos Dados: Os autores declaram ter seguido os protocolos da sua instituição acerca da publicação dos dados de doentes.

Consentimento: Consentimento do doente para publicação obtido. Proveniência e Revisão por Pares: Não comissionado; revisão externa por pares.

\section{Ethical Disclosures}

Conflicts of Interest: The authors have no conflicts of interest to declare.

Financing Support: This work has not received any contribution, grant or scholarship.

Confidentiality of Data: The authors declare that they have followed the protocols of their work center on the publication of data from patients.

Patient Consent: Consent for publication was obtained.

Provenance and Peer Review: Not commissioned; externally peer reviewed.

\section{References / Referências}

1. Poddar M, Chetty Y, Chetty VT. How does obesity affect the endocrine system? A narrative review. Clin Obesity. 2017; 7: 136-44.

2. Blüher M. Obesity: global epidemiology and pathogenesis. Nat Rev Endocrinol. 2019;15:288-98. doi: 10.1038/s41574-019-0176-8.

3. World Health Organization website. Overweight and Obesity. [Accessed on 24th April 2020]. Available at: https://www.who.int/news-room/factsheets/detail/obesity-andoverweight

4. Gregório MJ., Obesity as a Major Public Health Problem in Portugal: Achievements and Challenges. Port J Public Health. 2018; 36: I-II.

5. Abdelaal M, le Roux CW, Docherty NG. Morbidity and mortality associated with obesity. Ann Transl Med. 2017;5:161. doi: 10.21037/ atm.2017.03.107.

6. Frank J. Origins of the obesity pandemic can be analyzed. Nature. 2016; 532:149.

7. American Diabetes Association. Obesity Management for the Treatment of Type 2 Diabetes: Standards of Medical Care in Diabetes-2020. Diabetes Care 2020; 43(Supp 1): S89-S97.
8. American Diabetes Association. Classification and Diagnosis of Diabetes: Standards of Medical Care in Diabetes-2020. Diabetes Care. 2020; 43(Supp 1):S14-S31

9. Misra S, Oliver N, Dornhorst A. Diabetic ketoacidosis: not always due to type 1 diabetes. BMJ. 2013;346:f3501.

10. French EK, Donihi AC, Korytkowski MT. Diabetic ketoacidosis and hyperosmolar hyperglycemic syndrome: review of acute decompensated diabetes in adult patients. BMJ. 2019; 365:11114. doi: 10.1136/bmj.11114

11. Tran TT, Pease A, Wood AJ, Zajac JD, Mårtensson J, Bellomo R, et al. Review of Evidence for Adult Diabetic Ketoacidosis Management Protocols. Front Endocrinol. 2017; 8: 106. doi: 10.3389/fendo.2017.00106

12. Yu X, Zhang S, and Zhang L. Newer perspectives of mechanisms for euglycemic diabetic ketoacidosis. Int J Endocrinol. 2018; 2018: 7074868. doi: $10.1155 / 2018 / 7074868$.

13. Thiruvenkatarajan V, Meyer EJ, Nanjappa N, Van Wijk RM, Jesudason D. Perioperative diabetic ketoacidosis associated with sodium-glucose cotransporter-2 inhibitors: a systematic review. Br J Anaesth. 2019;123:2736. doi: 10.1016/j.bja.2019.03.028.

14. Andalib A, Elbahrawy A, Alshlwi S, Alkhamis A, Hu W, Demyttenaere $\mathrm{S}$, et al. Diabetic ketoacidosis following bariatric surgery in patients with type 2 diabetes. Diabetes Care. 2016;39: e121-e122. doi: 10.2337/dc160280.

15. Rizo IM, Apovian CM. Diabetic ketoacidosis post bariatric surgery. Front Endocrinol. 2019;9:812. doi: 10.3389/fendo.2018.00812. PMID: 30697192; PMCID: PMC6340926.

16. Valkenborgh T, Bral P. Starvation-induced ketoacidosis in bariatric surgery: a case report. Acta Anaesthesiol Belg. 2013;64:115-7.

17. Song R, Cao S. Post-bariatric surgery starvation ketoacidosis and lipase elevation in the absence of DKA or pancreatitis. Am J Emerg Med. 2018;36:525.e3-525.e5. doi: 10.1016/j.ajem.2017.10.068.

18. Ilie IR. The endocrine pancreas and diabetes mellitus. In: Introduction to Endocrinology. Berlin: Springer; 2020.

19. Tridgell DM, Spiekerman C, Wang RS, Greenbaum CJ. Interaction of onset and duration of diabetes on the percent of GAD and IA-2 antibodypositive subjects in the type 1 diabetes genetics consortium database. Diabetes Care. 2011;34:988-93. doi: 10.2337/dc10-1903.

20. Park JY. Prediction of type 2 diabetes remission after bariatric or metabolic surgery. J Obes Metab Syndr. 2018;27:213-22. doi: 10.7570/ jomes.2018.27.4.213.

21. Busetto L, Dicker D, Azran C, Batterham RL, Farpour-Lambert N, Fried M, et al. Practical Recommendations of the Obesity Management Task Force of the European Association for the Study of Obesity for the PostBariatric Surgery Medical Management. Obes Facts. 2017;10:597-632. doi: $10.1159 / 000481825$.

22. Heber D, Greenway FL, Kaplan LM, Livingston E, Salvador J, Still C. Endocrine and nutritional management of the post-bariatric surgery patient: an Endocrine Society Clinical Practice Guideline. J Clin Endocrinol Metab. 2010; 95:4823-43.

23. Alves M, Pedrosa C, Freitas C, Rocha G, Albuquerque I, Sequeira Duarte J, et al. Orientação nutricional e da terapêutica farmacológica da diabetes após cirurgia bariátrica. Rev Port Endocrinol Diabetes Metab. 2019;14:58-67. 